\title{
The Heritage-Making Conundrum in Asian Cities: Real, Transformed and Imagined Legacies
}

\author{
David Ocón \\ School of Technology for the Arts, RP Singapore
}

\begin{abstract}
The process of heritage-making is far from straightforward. Defining the meaning of heritage in young nations and cities where land availability is limited is a challenging exercise. It often crosses the paths of history, religion, memoryshaping, development, and identity-building. It requires fluent communication channels between civil society, local organisations and governments. Willingness to cooperate from all the parties involved is essential; dialogue a must.

In land-scarce or densely populated Asian cities, expansion and growth is colliding with the preservation of legacies, the past and memory. This paper examines regional case studies from Hong Kong, Manila and Singapore, where preservation of cultural patrimony, development and daily life follow conflicting paths. It sheds light on the policies behind heritage-making, where the interaction with concepts such as memory, identity, urban planning, progress, and nature, creates complex situations and requires imaginative resolutions.
\end{abstract}

Keywords: Asian Cities; Urban Heritage Preservation; Singapore Heritage; Hong Kong Heritage; Manila Heritage

\section{Heritage-making and humanity}

$\mathrm{W}$

hat we decide to do with our heritage "defines the kind of civilisation, or nation, or community, or family or person we are - who we are" (Ting, 2015, p. 9). Ting's notion is explored in this paper through three case studies presented from major Asian tropical cities: Hong Kong, Manila and Singapore. The three cities pose fundamental questions surrounding the handling of heritage issues in this region today. The three encapsulate many of the complexities encountered when heritage - tangible and intangible is put into conversation with crucial issues such as development and the construction of key infrastructure, the safeguarding of memories, or identity-building. The three case studies corroborate Ting's statement. 
The case of Hong Kong's To Kwa Wan station is the first presented in this paper. To Kwa Wan is an unassuming mixed residential and commercial area the eastern shore of Hong Kong's Kowloon peninsula. The discovery of heritage relics from Song and Yuan dynasties at the site where a new vital railway line was being constructed unveiled a heritage dilemma: should these relics be preserved at any cost? Should they be preserved in situ or moved to another location to allow construction to resume? What meaning does this type of heritage symbol have for contemporary Hong Kongers? Can heritage relics, unknown to the public until then, be considered part of its modern identity?

Manila's heritage clash is the second case presented, and it is of a different nature. The Rizal monument, although artistically half-hearted, is popular, visible and widely accessible to the public in one of the country's most visited parks. It is a very dear symbol and a tribute to the national hero that died for the Philippines. Controversy was sparked when a foreign element was introduced - a mega condominium threatening the monument's sightline. The dispute over heritage versus development aroused a number of critical questions: can a significant monument's sightline be considered part of its realm? Should a sightline even be considered heritage and thus be subjected to preservation? How much should heritage preservation issues be allowed to slow down progress in rapidly-developing cities like Manila hungry for space to accommodate new expansion?

The last case presented in this paper is that of Singapore's Bukit Brown Cemetery. The graveyard had existed for more than a hundred years and, although largely ignored by the public, it was relatively untouched and well-preserved. The sudden threat of having it spoilt or even lost completely to construction, first to an eight-lane highway and subsequently to residential developments, ignited the heritage predicament: can a cemetery be representative of a country's heritage? Can a land-scarce city-state like Singapore afford to have 'dormant' premium space? How should the heritage intangibility of a cemetery be preserved? What constitutes Singapore's 'real' heritage?

None of the three heritage preservation conundrums presented in this paper is easy to resolve. In today's busy, land-deprived and fast-growing tropical Asian cities, the management of heritage assets can easily turn into heritage dilemmas for policy-makers and governments, and rarely are choices conflict-free or simple. A few years ago, cases like the three investigated in this paper would have attracted little attention from the media and the public. Today, however, governments' decisions about heritage are meticulously scrutinised by better organised heritage groups and more heritage-aware citizens who are emboldened to speak up and are conscious of their rights. They also leverage powerful social media tools suited to rapidly mobilising people and opinions.

In 1972, UNESCO's Convention concerning the Protection of the World Cultural and Natural Heritage recommended giving cultural and natural heritage "an active function in community life and to integrate into the overall policy the achievements of our time, the values of the past and the beauty of nature" (UNESCO, 1972). Almost half a century later, the pressing 
daily realities of fast-developing Asian tropical cities has not stopped interrogating the contemporaneity, and even validity, of that declaration. When heritage preservation implies delays and halts to progress or growth, the betterment of infrastructure, accessibility and connectivity, decision-making is not straightforward. The three cases examined in this paper illustrate the difficulties encountered by tropical Asian cities to amalgamate the preservation of valuable heritage with pressing development needs.

\title{
To Kwa Wan station relics, an unexpected halt for Hong Kong's metro
}

\author{
"Heritage is a nomadic term, which travels easily... \\ It sets up residence in streets broad and narrow, royal palaces and railway sidings..."
}

(Samuel, 1994, p. 205)

Relics, artefacts or structures revealing traces of the past of a society or group of people, at times dating back hundreds of years, can emerge in the most inconvenient of places. They occasionally stand in the path of development and their presence, wanted or not, can delay and even stop construction of projected infrastructure. This is exemplified by the relics recently found as part of the construction of the Sha Tin to Central Link (SCL) of Hong Kong's Mass Transit Railway (MTR). This rail link is projected to connect Hong Kong's Northern territories (Tai Wai station) with Kowloon (Hung Hom) in 2018 and with Hong Kong Island (Admiralty) in 2020. The total cost of the project has been estimated at close to 80 billion (Fung, 2014f).

At the end of 2012, a vast array of relics and structures dating from the Song dynasty (9601279 AD) and the Yuan dynasty (1279-1368 AD) were uncovered during excavation. The ruins appeared at a site previously called Sacred Hill or Hill of the King of the Sung, which was levelled during the Japanese occupation of Hong Kong in the 1940s as part of the extension works for the former Kai Tak airport. Today, the area is known as To Kwa Wan, a mixed busy residential and commercial area at the eastern shore of Kowloon peninsula. The relics emerged in the area surrounding the projected SCL's To Kwa Wan metro station.

At first a team of archaeologists commissioned by the MTR Corporation studied the site. But in May 2014, amid criticism of mishandling of the artefacts from conservation groups - for example the removal of four wells from the site - the Hong Kong government conservation advisers from the Antiquities Advisory Board (AAB) stepped in. Fierce debate sparked between conservationists, government agencies, and residents. Some wanted the antiquities removed quickly so that the railway could be built as soon as possible. Others asked for them to be preserved at the site, still others wanted to preserve the relics but advocated for a change of location in order to allow for the construction to resume and avoid higher costs. The media picked up the story and it became a local controversy. The issue was often framed as a dispute between heritage conservation versus building progress (Archaeology News Network, 2014). 
Rapidly the story reached many of the levels that today form the heritage-making predicament in large and fast-paced Asian cities such as metropolitan Hong Kong: Were the relics discovered valuable enough? And if so, should they be preserved in situ or dismantled, reconstructed and displayed somewhere else? How much was the government (and thus, taxpayers) ready to pay to preserve the heritage found? Should the government involve civil society and other stakeholders in the decisions related to the site? How much nuisance (extra works, delays, noise, and inaccessibility) would preservation mean for residents of the To Kwa Wan neighbourhood? Could the relics unveiled be considered part of the identity of the busy financial hub Hong Kong has transformed into?

\section{The value of the relics}

Since the discovery of the relics, doubts have been cast over their nature and origin, particularly whether they were from the Song or the Yuan dynasty, and whether they were of great value. This initial doubt, which loomed over the nature of the relics for months, led to a lot of speculation. Some experts found the relics revealed exceptional, as they provided evidence of Hong Kong's ancient trade with the Chinese regions of Guangdong, Fujian, Zhejiang and Jiangxi. For Dr Ho Koon-wan, a Song dynasty specialist from Hong Kong Polytechnic University, the remnants unearthed could have been the site of the office of Kwun Fu Cheung, the official salt production unit during the Song dynasty. His theory was seconded by another historian, Dr Chiu Yu-lok, of Hong Kong Open University, who found similarities between the MTR excavation and pictures showing ancient salt production methods in Exploitation of the Works of Nature, a $17^{\text {th }}$ century Chinese science and technology encyclopaedia (Fung, 2014c).

However, other experts were much less positive in their assessment of the relics. For Professor Tang Chung, director of Chinese University of Hong Kong's Centre for Chinese Archaeology and Art, the site was far from rare in Hong Kong and the artefacts were "just some wells and house structures which had not been kept intact. They only represent some common settlements at that time". While William Meacham, a former chairman of the Hong Kong Archaeological Society, depicted the remains as "barely an ordinary village" (Fung, 2014f). Both argued that the relics, in keeping with international standards, could safely be moved to museums. Similarly, Dr Sharon Wong Wai-yee, a Chinese University of Hong Kong archaeologist specialising in trade ceramics, found the pieces to be largely similar to past discoveries and not of particularly high quality (Fung, 2015). The Hong Kong Archaeological Society urged the government to engage more experts familiar with archaeology in southern China to ascertain the era of the relics (Wong \& Fung, 2014).

\section{Preservation in situ or dismantlement}

Another heritage dispute in relation to the To Kwa Wan relics was whether they should be preserved in situ or be dismantled and displayed elsewhere. The discovery of the relics caused a delay in the completion of the railway project of more than a year and many To Kwa Wan residents opposed further delays in order to preserve them on site; at several 
instances they filed petitions against the preservation in situ, demanding that the relics concerned be removed temporarily so that the railway could be opened as soon as possible (Wong, 2014). Some archaeologists were also clearly against the in situ preservation of the very scattered relics, stressing the public's misunderstanding about the meaning of in situ preservation and the overall unawareness of its implications.

Conversely, the government's handling of the relics was widely criticised by some civil society groups that advocated for in situ preservation of the relics. Albert Lai Kwong-tak, of lobby group Professional Commons, called on the government to take over the site and invite members of the public to oversee the work. He spoke of a conflict of interest as the rail operator would want to get on with excavation work needed for the railway (Lee \& Fung, 2014). Other heritage activists such as those from the Sacred Hill Monument Concern Group, highlighted the opacity with which the government handled the site and campaigned for in situ preservation, advocating for public consultation on ways to conserve the relics after the archaeological study is completed (Archaeology News Network, 2014). Katty Law Ngarning, a member of the group, depicted the To Kwa Wan case as an illustration of the conflict of interest issues that developers face in archaeological sites that could threaten their own projects. For Law Ngar-ning, the railway company had "vested commercial interests and...incentives to get the railway built as soon as possible" (Fung, 2015).

For Hong Kong Polytechnic University transport analyst Dr Hung Wing-tat, the government had not been transparent enough in providing information (Lee, 2014). And retired archaeologist William Meacham complained that local archaeologists and the community had not been consulted before deciding on the conservation approach, calling the handling of the site "a major flaw" (Wong \& Fung, 2014). Dr Wong Wai-yee proposed a halfway solution: incorporating the relics in the future MTR station for display in the hopes that this "station-cum museum", the first of its kind in Hong Kong, could get more people interested in archaeology (Fung, 2015).

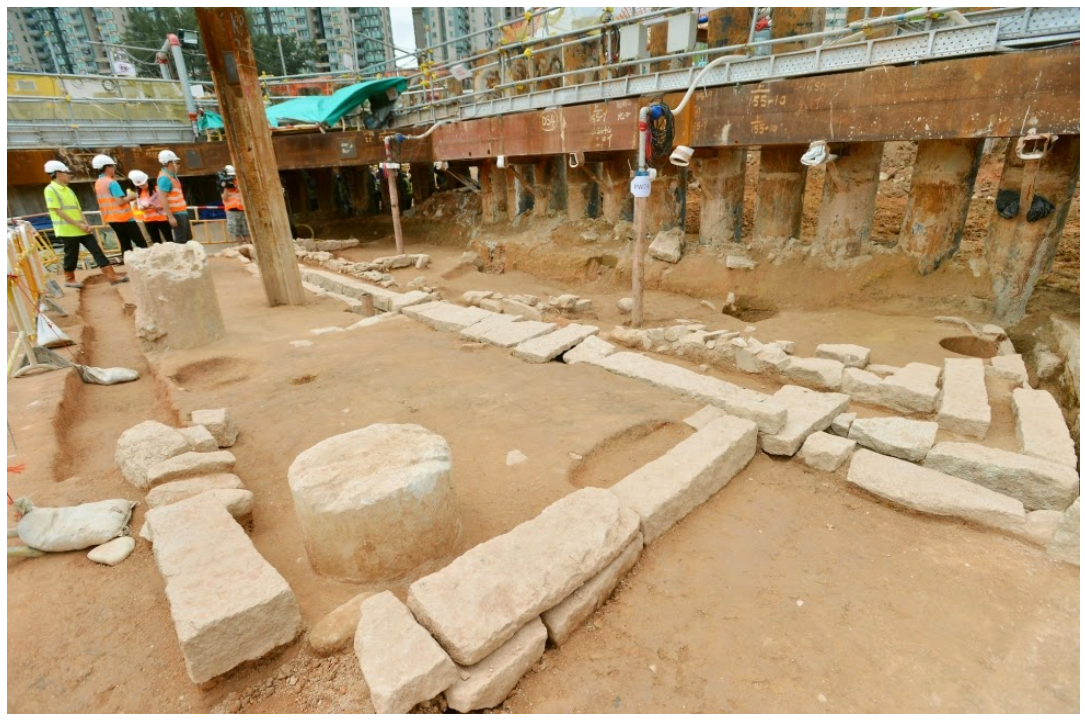

Figure 1

Archaeological site in the the area around the MTR's new To Kwa Wan station (South China Morning Post, 2014) 


\section{How much are we willing to pay for the preservation of heritage?}

One of the most intense debates regarding the safeguarding of the heritage relics found at the To Kwa Wan site was around the high cost of preservation. The initial extended archaeological dig and work to protect the relics added more than HK\$3 billion to the initial projected budget of HK\$79.3 billion, and delayed the construction by 11 months (Wong, 2014). The in situ preservation of just seven of the hundreds of archaeological features uncovered at the To Kwa Wan station for passengers to view in their original locations (two wells, a stone footpath and a group of building remnants, some dating back to the Song or Yuan dynasties, and a well dating back to late Qing dynasty), was estimated to cost a further HK\$1 billion (Wong \& Fung, 2014).

The controversy regarding the cost of safeguarding and preserving heritage was further illustrated in a case that emerged at the end of 2014. The Hong Kong government was confronted with several options regarding the engineering works to protect a medieval well located on the site planned for the new station's roof. Four options were laid down, including removal and reconstruction, with costs that ranged from $\mathrm{HK} \$ 10$ million to $\mathrm{HK} \$ 1.3$ billion. The latter would also mean a further delay of four months to the project, adding to the 11 month deferment it had already experienced. This further postponement was estimated to cost millions per day at possibly HK\$250 million or more per month of delay (Wong, 2014; Archaeology News Network, 2014).

Civil society groups such as Heritage Watch and The Professional Commons disregarded the high cost of the preservation of the well in situ as a determining factor. In a letter to the MTR Corporation, they reminded the company of its legal responsibilities in protecting antiquities and urged the rail operator to perform a comprehensive assessment of the relics' value and to take all reasonable measures to protect the antiquities discovered (Kao, 2014). Some Hong Kong archaeologists called for the establishment of an independent expert panel to reassess the value of relics unearthed in To Kwa Wan and warned that to preserve more relics could be a waste of public money. Professor Tang Chung argued that the relics uncovered were not of such archaeological value to make them worth preserving in situ and that spending billions of dollars on them would be "against any common sense in archaeology in the world" (Fung, 2014f).

Eventually, the Hong Kong government chose the cheapest option, which meant moving the well to another location at a cost of $\mathrm{HK} \$ 10$ million rather than facing higher costs and further delays. "We do not conserve for the sake of conservation. Otherwise it is not very meaningful", declared Development minister Paul Chan Mo-po to justify the decision (Fung, 2014e).

\section{The relics are part of our identity}

Hong Kong is notorious for positioning development ahead of heritage preservation. For decades, growth and progress counted more than the protection and safeguarding of 
heritage. The Commissioner for Heritage's Office was only set up in 2008 after public outcry a year earlier over the demolition of Queen's Pier and ultimately its occupation by young protestors, which put the government's heritage preservation policies under public scrutiny. However, things are changing fast in Hong Kong and over the last decade dozens of heritage buildings have been preserved and revitalised. In some cases the government now cooperates with NGOs to allocate new functions and meanings to these heritage buildings. ${ }^{1}$ According to José Yam Ho-san, Hong Kong's Commissioner of Heritage, today more "organic" uses have replaced the "too passive" old way of preserving buildings (Tsui \& Yao, 2016). More than ever before, the government seems committed to striking a balance between development and conservation (Government of Hong Kong, 2014).

Koboldt calls cultural heritage assets "an expression or representation of the cultural identity of a society in a particular period" (Koboldt, 1997: 68). The trend observed in the last few years in Hong Kong illustrates this. For Tim Ko Tim-keung, Hong Kong's Antiquities Advisory Board member, the discovery of the relics at To Kwa Wan station could help reconstruct Hong Kong's identity, even if the price to pay is modifications or delays in the construction of the railway (Lee \& Fung, 2014). Others, such as architect Philip Liao Yi-kang, advocate for a more holistic approach to heritage preservation and cite Rome as an example where relics dating to different periods are well displayed, allowing for stories to be reconstructed in such a way that visitors are reconnected with the past (Wong \& Fung, 2014).

In Hong Kong, civil society groups, activists, experts, and concerned citizens have recently publicly expressed their discontent when the government mismanaged heritage buildings or sites. At times, cultural identity claims were at the forefront of the protests. The To Kwa Wan controversy builds upon that trend and suggests that civil society is now more aware of heritage as part of their identity.

\section{A compromise reached}

Ultimately, as a way to address the heritage impasse originated by the discovery of the ruins, the authorities in Hong Kong proposed a partial redesign of To Kwa Wan station to preserve and display some of the centuries-old relics inside the station. To do that, some of the projected facilities had to be moved (e.g. a ventilation facility), the station concourse had to be extended southwards to accommodate an additional plant room, the roof of the station had to be modified to form a trough to reinstate a well from the Song-Yuan period with a transparent panel placed at the bottom of the trough so that passengers could view the well from underneath. According to Hong Kong's Leisure and Cultural Services Department, a park will be built on top of the station to display some relics and promote archaeological education. Other relics are to be dismantled and then reassembled in nearby locations or in museums. This decision was not exempt from criticism and some Antiquities Advisory Board members disapproved of the plans as they would fail to bring history back to life. Some also

\footnotetext{
1 For more information on Hong Kong's Conservation Policy and Revitalisation projects visit Commissioner for Heritage's Office website: https://www.heritage.gov.hk/en/index.htm.
} 
objected to the ceiling display, saying passengers may not have time to look up and appreciate the relics as they commute ("To Kwa Wan station to display," 2017).
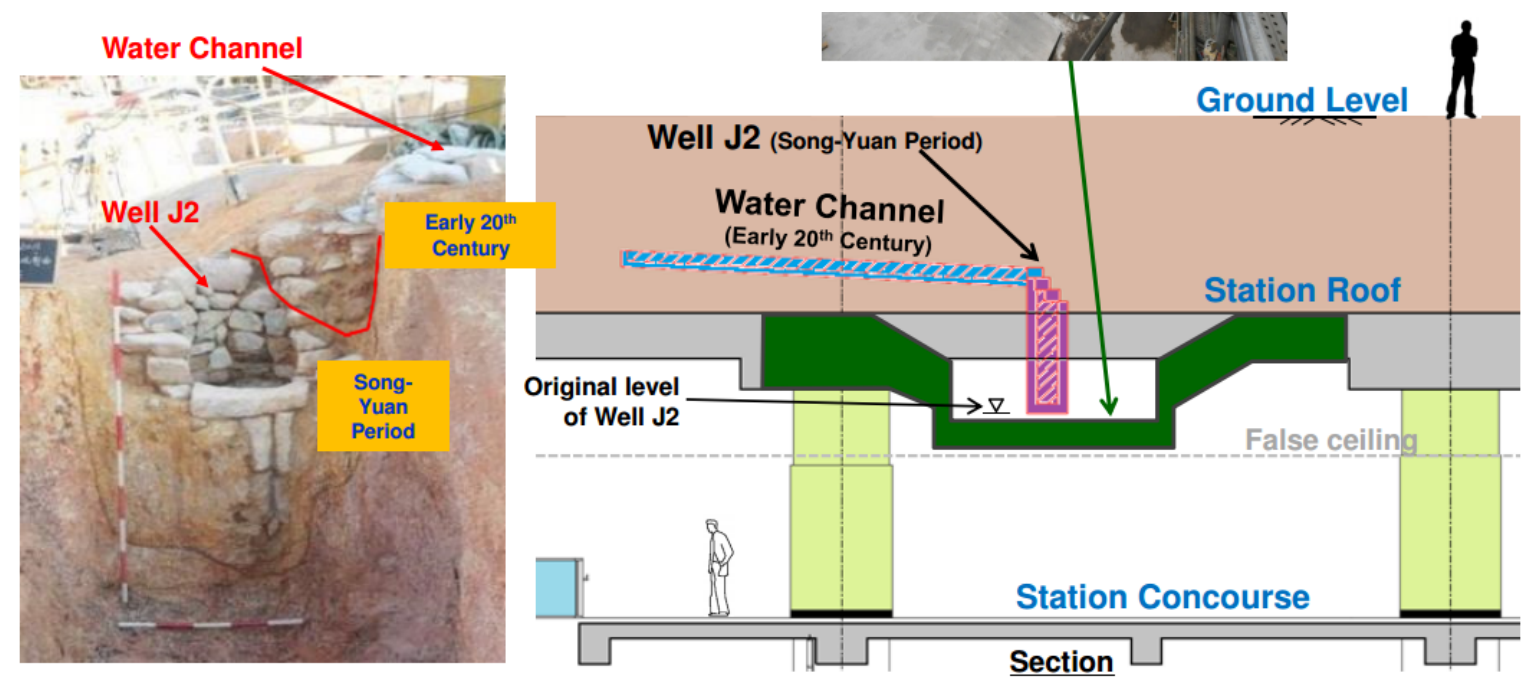

Figure 2. On the left, the well preserved in situ. On the right, Hong Kong government's redesign proposal for To Kwa Wan station (Antiquities Advisory Board, 2017)

Belinda Yuen confers to the influences of globalization the responsibility in the rise of heritage conservation "as a growing need to preserve the past, both for continued economic growth and for strengthening national cultural identity" (Yuen, 2005). Her assertion encapsulates the fundamental paradox found in To Kwa Wan's heritage conundrum: development, which threatens to destroy heritage, is precisely what can facilitate and empower its preservation.

\section{Torre de Manila: condo with a view, heritage with none}

"Each one writes history according to his convenience" José Rizal, letter to Blumentritt, 1886

The Rizal monument is a memorial located in Rizal Park, Manila, built to commemorate the Filipino national hero, José Rizal. It was planned through Act No. 243 of September 28, 1901, and was constructed during the American colonial period in the Philippines. The monument's original title is Motto Stella or "guiding star", the title given by its designer, the Swiss sculptor Richard Kissling. The monument is composed of a standing bronze sculpture of Rizal in an overcoat holding a book that represents his novels Noli Me Tángere and El filibusterismo, with an obelisk as his backdrop, set on a granite stone base within which his remains are interred. On the monument's front pedestal there is a plaque that reads: "To the memory of José Rizal, patriot and martyr, executed on Bagumbayan Field December Thirtieth 1896. This monument is dedicated by the people of the Philippine Islands". Rizal Monument and Rizal Park are administered by the National Parks Development Committee (NPDC), an attached agency of the Department of Tourism. The perimeter of the monument 
is guarded continuously by the Philippine Marine Corps' Marine Security and Escort Group, the changing of the guard having become a daily ritual. The exact location where Rizal was executed is about 100 meters north-northwest of the monument.

The Rizal monument is understated, being just 12.7 meters high it does not tower and neither does it contain great decorative details. It "shies away from magnificence" and "grandiose aesthetic claims" (Official Gazette of the Republic of the Philippines, 2013: Part $\mathrm{VI}$ ). Over the years it has become a patriotic landmark and a symbol of the Philippines' struggle for independence. As with other iconic monuments worldwide, this constructed heritage has surpassed its artistic significance, has transcended the realm of the tangible, and has attained what Throsby defines as "cultural capital" - an asset that "embodies the community's valuation....in terms of its social, historical, or cultural dimension" (Throsby, 1997, p. 15). Accordingly, Manila City Councillor, DJ Bagatsing speaks of the monument's "historical legacy", "the most important monument in the country" (Ranada, 2013a).

\section{Heritage's sight threatened}

The year 2012 saw a disruption in the otherwise overall peaceful existence of the Rizal monument. The start of the construction of a 49-story condominium, named Torre de Manila (Manila tower), sparked controversy and public outrage in the Philippines' capital city. The condominium developer, DMCI Homes, started construction on an empty lot located across the street from Rizal Park. Torre de Manila was meant to be located right behind the Rizal shrine, prominently visible to anyone facing, looking at, or taking photos of Rizal's resting place. The condominium was initially opposed by some Manila residents and other concerned citizens because its floor-to-area ratio exceeded the allotted limit for buildings in its location, thus burdening the limited utility pipes, electricity, and water facilities in the area (Ranada, 2014b). However the louder voices came from heritage enthusiasts who claimed that the residential building, once completed, would dwarf Rizal's shrine and resting place of the national hero.

Michael Hutter expands the traditional scope of heritage to include the qualities found in the intangibility of buildings, historical sites or sculptures (Hutter, 1997, p. 4). For Manila heritage advocates, the Rizal monument's intangibility was crucial, with its front view, it's only remaining unrestricted sightline, as the most important perspective. Therefore, the condominium would ruin what they called "the sanctity of the Rizal sightline" (Ranada, 2013b). Torre de Manila was dubbed by many as the "Terror of Manila" and "pambansang photobomb" [the national photo spoiler] (Ranada, 2014e). The National Parks Development Committee (NPDC) joined heritage advocates and recommended imposing limitations on the height and design of constructions in the vicinity of historical landmarks so as not to block or obstruct historical views and preserve their prominence. In the case of Torre de Manila, it strongly encouraged the developer to revise the design of the condominium.

Heritage activists were partially grounding their claims on the 'Guidelines on monuments honoring national heroes, illustrious Filipinos and other personages', by the National 
Historical Commission of the Philippines (NHCP), the government agency dealing directly with national monuments and cultural and historical landmarks. According to NHCP, "Monuments should be given due prominence since they symbolize national significance.... The monument should preferably be the focal point of a city or town center" and one measure for preserving dominance is to "keep vista points and visual corridors to monuments clear for unobstructed viewing appreciation and photographic opportunities". The Republic Act 10066, also known as National Cultural Heritage Act of 2009, establishes that a heritage zone shall be maintained by the local government and the appearance of its monuments maintained close to when "the area was of most importance to Philippine history", and gives the NHCP the power to issue a Cease and Desist Order "when the physical integrity of the national cultural treasures or important cultural properties are found to be in danger of destruction or significant alteration from its original state" (Congress of the Philippines, 2009). However, while in the first instance NHCP seemed sympathetic to the claims made by heritage advocates in the Torre de Manila conflict, eventually the commission changed its stance and did not support their cause.

\section{A matter of national identity}

According to Yuen, the growing need to preserve the past in today's societies has led to the fostering of active conservation of heritage as, among other reasons, a way to strengthen national cultural identity (Yuen, 2005). In the case of the Torre de Manila condominium, the defence of cultural and national Filipino identity as represented by the Rizal monument itself, but also by its pristine sightline, was one of the main reasons to demand the halt of construction. Pia Cayetano, Senator of the Philippines, who at the time of the controversy chaired the Senate Committee on Education, Arts and Culture, claimed that it was about time Filipinos "as a people, take the protection of our history, culture and heritage more seriously as these make up the intangible ideals that bind us as Filipinos and define our national identity" (Felongoo, 2015). Manila City Councillor, DJ Bagatsing, advocated for responsible development without crushing both heritage and historical identity, and Carlos Celdran, one of the first heritage campaigners to put the Torre de Manila case in the spotlight, defined the construction of the building as "offensive to our national hero, our national identity" (Ranada, 2013a).

This sentiment was not shared by everyone in the Philippines. National Artist for Literature, F. Sionil José, one of the most widely read Filipino writers, was among those who opposed the claims by heritage conservationists to justify the removal of Torre de Manila from the backdrop of the Rizal Monument. José labelled the claims made by heritage enthusiast as "a heavy overdose of nationalism" (Sionil José, 2015), as no law prohibits its construction and the building was erected on private property after obtaining all the required government approvals. 


\section{Should a sightline be considered heritage and thus, be preserved?}

Over the ensuing years heritage advocates were actively in opposition to the construction of the Torre de Manila condominium. A change.org petition to demolish the condominium was filed by cultural activists; it attained over 11,000 signatures. The petition to demolish Torre de Manila was addressed not only to the developer of the condominium, DMCI Homes, but also to the NHCP, the NCCA, the Senate of the Philippines, the Mayor of the City of Manila, the Manila City Council, and the Manila City Planning Office (\#DemolishTorreDeManila, n.d.).

As a result of the claim, in March 2013, the Manila City Council approved Ordinance 8310 which prohibited any construction or development that would ruin the sightline of all historical and cultural sites within the city. Ultimately, in November 2013, the city council suspended the building permit for Torre de Manila to allow for a roundtable discussion between the developer $\mathrm{DMCl}$ and the groups opposing the project. Heritage campaigner Carlos Celdran hailed the decision as a victory of "historical significance over reckless development" (Ranada, 2013c).

However, in January 2014, the Manila Council reconsidered its decision and the construction of the condominium resumed. Among the conditions made by the Manila Council to $\mathrm{DMCl}$ Homes was for the real estate company to "plant two layers of very tall trees between Torre de Manila and the Rizal Monument to strategically enhance the vista". Manila Council's decision led to disappointment among heritage advocates: Senator Pia Cayetano expressed her distress "to see something disrespectful [done] to [what is] historic and cultural" (Ranada, 2014c).

The heritage activists counterattacked. As a reaction to Manila Council's resolution, in September that same year, the Knights of Rizal, a civil society group created in honour of the national hero, filed a petition before the Supreme Court seeking the demolition of the condominium. The group, citing the Cultural Properties Preservation and Protection Act (Republic Act 4846), the National Cultural Heritage Act, and the building's zoning violations, understood that the high-rise building threatened to ruin the "visual dominance" of the monument and declared that Torre de Manila qualified as a "nuisance" (Knights of Rizal, 2014). This term is defined as "any act, omission, establishment, condition of property, or anything else which annoys or offends the senses; or shocks, defies or disregards decency or morality" (The Civil Code of the Philippines, 1949).

The National Commission for Culture and the Arts (NCCA) joined the heritage campaign and issued a 'cease and desist order' (CDO) against Torre de Manila as it destroyed or significantly altered the view of the Rizal Monument. The NCCA cited the National Cultural Heritage Act of 2009, stating that the Rizal National Monument and the rest of the park were "cultural property characterized as built heritage" (Macaraig, 2015). Senator Pia Cayetano backed the NCCA "in asserting its mandate to safeguard our heritage [...] entitled to full protection under our national heritage law" (Senate of the Philippines, 2015). 
Ultimately, the heritage claims were heard and in June 2015 the Supreme Court of the Philippines issued a temporary restraining order, suspending Torre de Manila's construction. Shortly after, the Solicitor General, Florin Hilbay, arguing that the Rizal Monument's physical integrity necessarily includes its sightline, issued a memorandum asking the Supreme Court to order DMCI Homes to demolish Torre de Manila at its own expense.

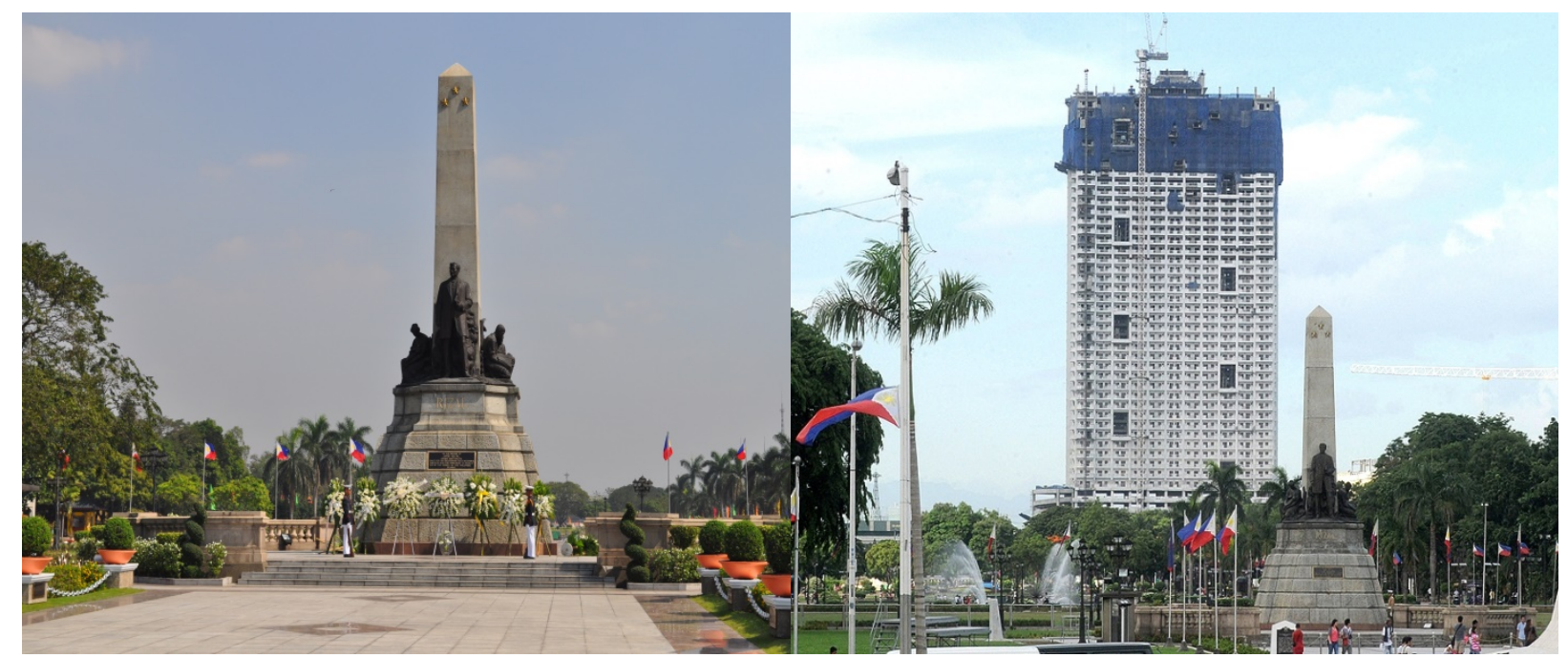

Figure 3. The Rizal Monument in Rizal Day 2009 https://commons.wikimedia.org/wiki/File:Rizal_Mo nument_on_Rizal_Day.jpg Public domain.
Figure 4. Construction of the controversial Torre de Manila condominium behind the Rizal Monument in Manila (Directo, 2015)

\section{A view vs. development}

In April 2017, less than two years after its previous ruling on the Torre de Manila case, the Supreme Court of the Philippines dismissed the petition against the construction of the condominium, lifted its temporary restraining order and gave the green light to the resumption of works. According to the Supreme Court's ruling, the construction of the condominium had not violated any law that affects the background view, vista, sightline or setting of the Rizal Monument, as nothing "disallows the construction of a building outside the boundaries of a historic site or facility" (Supreme Court of the Philippines, 2017).

The Supreme Court also highlighted that the complainant, the Knights of Rizal, had proposed a similar concept in the 1950s when it suggested building a national theatre on the open space right behind the Rizal Monument, 286 metres from it and 29.25 meters high. Again in 2013 the group proposed the construction of a Rizal Center on Rizal park, which was disapproved by the NHCR and the Department of Tourism, as the centre "would have dwarfed the Rizal Monument with its size and proximity". To the Supreme Court, the Knights of Rizal had come to court with "unclean hands" and their petition therefore had adequate grounds for dismissal (Supreme Court of the Philippines, 2017).

The construction of Torre de Manila resumed shortly after the Supreme Court ruling. DMCI Homes, the condominium developer, welcomed the ruling (Gonzales, 2017). For opponents 
to the condominium such as Senator Pia Cayetano, the fight against Torre de Manila stressed "the importance of protecting and preserving our cultural heritage and historical landmarks" (Porcalla, 2017); the Knights of Rizal called it a "test case for Philippine heritage" (Marcelo, 2017).

The heritage-making and preservation dilemma surrounding the Rizal Monument in Manila poses several questions that this paper has intended to address. Nevertheless, this case revolves around one central question: can a tangible heritage monument's sightline be considered part of it, and as such be legally protected? Outside of the Philippines the Torre de Manila controversy has largely gone unnoticed. This probably would not have been the case if the heritage monument's sightline threatened by mega condominiums were, for instance, Washington DC's Lincoln Memorial or Beijing's Forbidden City.

Ultimately, the value attached to a monument lies in a variety of aspects: its location, its artistic value, the stories that lie behind its construction, its historical meaning, its depiction of a significant historical milestone or figure. The significance of a monument can also be determined by the relevance visitors attach to it, by how people experience and interact with it. An old Tagalog limerick rings true in this Filipino heritage conundrum: Konting bato, konting semento, monumento - a little rock, a little cement, then you have a monument.

\section{Bukit Brown Cemetery: heritage vs. development in Singapore}

"In the long run we are all dead" John Maynard Keynes, 1923

For most of its relatively short history as a nation, Singapore has had to make challenging decisions regarding the use of its limited land. When in need of space for the construction of roads, housing facilities and other developments, there are few areas and structures spared to allow for the new needs. In such a land-scarce and densely-populated country, space is a highly-sought and tightly controlled commodity.

Religious buildings are also subjected to demolition and relocation in Singapore. They are treated as any other building which may come in the way of development and resettlement. ${ }^{2}$ In some exceptional cases, religious buildings may be considered to be of special historic, architectural or artistic value and instead of demolition or relocation, are gazetted as national

\footnotetext{
${ }^{2}$ A policy statement was made in 1973 which stressed that "as people move out from old areas to be redeveloped temples, mosques or churches will have to give way to urban renewal or new development, unless they are of historical and architectural value". This approach was also illustrated in a statement in 1978 by Mr Tan Eng Liang, then Singapore's Senior Minister of State for National Development, who declared that "the resettlement policy is clear-cut, irrespective of religions, irrespective of owners and irrespective of organisations" (quoted in Kong, 1993).
} 
monuments by the National Heritage Board (NHB). ${ }^{3}$ Since 1973, when eight structures were designated national monuments, a total of 29 religious buildings (eleven churches, ten temples, five mosques, two synagogues and one shrine), have been preserved and safeguarded from development (Singapore Government, 2009). However, religious places that are not deemed historically and architecturally significant by the government are not preserved, even if they are recognised as sacred spaces (Kong, 2003, p. 357). As such, no burial ground or cemetery has entered Singapore's national monument category and, consequently, none has been preserved.

Cemeteries typically use a considerable amount of space and some of them, particularly older ones, can be located on premium and highly-sought land (Capels and Senville, 2006), which is often subjected to redevelopment. Choa Chu Kang Cemetery (CCKC) is Singapore's largest burial ground and currently the only public graveyard in operation. This $1.29 \mathrm{~km}^{2}$ state-owned cemetery created in 1947 contains over 200,000 graves and comprises Chinese, Christian, Ahmadiyya Jama'at, Muslim, Parsi, Bahá'í, Jewish, Hindu and Lawn cemeteries. So precious is land in today's Singapore that at CCKC the burial period for all graves is limited to 15 years, after which the remains of the deceased have to be exhumed. In the handling of faith matters in Singapore pragmatism is emphasised, and all religious places are treated equally - including burial grounds (Kong, 2002, p.1577).

\section{Space slated for redevelopment (another cemetery down)}

In Singapore, graves are frequently exhumed to give way to development. In the last few years, the total or partial dismantlement of several old and/or abandoned public cemeteries has been in the spotlight, leading to controversies that criss-cross issues such as development, progress, urban planning, history, memory-shaping, identity-building, and the right to rest in peace. Bukit Brown Municipal Cemetery (BBMC) is one of the largest and most prominent of those public cemeteries. ${ }^{4}$ It started as a private cemetery for the She Ong Kongsi, a Hokkien clan community for those with the surname Ong, which, from the 1870s until 1919, used the property for burials. The government then acquired the land under pressure to provide a public cemetery for the broader Chinese community, which opened in 1922 (Tsang, 2007). BBMC ceased operation in 1973 but still contains more than 100,000 tombs and is believed to be the largest Chinese cemetery outside China (The Economist,

\footnotetext{
${ }^{3}$ The NHB is a statutory board within the Government of Singapore under the jurisdiction of the Ministry of Culture, Community and Youth. It has so far gazetted 72 buildings and structures as national monuments.

${ }^{4}$ Bukit Brown is not the first cemetery to fall victim to urban sprawl. Bidadari Cemetery, which served Christian, Muslim, Hindu and Sinhalese communities, had around 143,000 graves and closed operation in 1973. Many notable people were buried there, including Augustine Podmore Williams, an English sailor whose story inspired Joseph Conrad's novel Lord Jim. Exhumation started in 2001, it was completed in 2006, and the cemetery was thus cleared to make way for roads, parks, transportation and housing. It is in the process of being turned into a high-value property due to its city fringe location (Singapore Property News, 2012; Jones Lang LaSalle, 2016; Property Guru, 2016). Another of these cemeteries is Choa Chu Kang Cemetery. In July 2017 the government announced that it will reduce its size by a third to make way for Tengah Air Base expansion, which will require the progressive exhumation of 80,500 Chinese and Muslim graves from 2018 (SLA, NEA, MND, 2017).
} 
2013). Some of its graves date back to the 1830s, including many from the country's pioneers that belonged to all paths of life: businessmen, manual labourers, industrialists and revolutionaries (Sun Yat Sen Nanyang Memorial Hall, 2013).

In September 2011, Singapore's Urban Redevelopment Authority (URA), Land Transport Authority (LTA) and the National Parks Board (NParks) announced that a new eight-lane road would be built over parts of BBCM to cater to increased traffic and to help ease the peak-hour congestion in the area (Singapore Government, 2011a). Details of the graves affected by the construction were published a few months later. The remaining parts of the cemetery and its surrounding land are slated for future redevelopment into a new housing estate and a train station.

\section{Heritage re-discovered}

The government's decision to build a highway crossing through Bukit Brown Cemetery met fierce resistance from several civil society groups that urged the government to rethink its plans. Among the groups were the Singapore Heritage Society (SHS), the Singapore Nature Society (SNS), the SOS Bukit Brown group, and All Things Bukit Brown. The first two produced position papers arguing why the road project should be halted, underscoring Bukit Brown's several levels of heritage worthy of preservation, and its ecological value and biodiversity. ${ }^{5}$ The Singapore government, not customarily inclined to engage in these kinds of public debate regarding its decisions, ${ }^{6}$ was faced with great public opposition and agreed to have a discussion with the civil society groups. Both government and non-governmental groups shared in the desire to retain and celebrate the heritage of Bukit Brown (BBC, 2012).

Ultimately the government pursued its plan of building the highway that is scheduled to be completed in 2018. Exhumation of the first batch of graves began in December 2013. Mr Tan Chuan-Jin, Singapore's Minister of State for National Development, justified the decision in the following terms: "We have sought to explore various possibilities for the road but there were no easy choices.... Planning for the long-term land use in land-scarce Singapore often requires us to make difficult decisions" (Singapore Government, 2011b). Civil society groups were disappointed with this decision, which was seen as the government choosing development at the expense of heritage (BBC, 2012).

\footnotetext{
${ }^{5}$ See Nature Society (Singapore)'s Position on Bukit Brown, 12 December 2011; and Singapore Heritage Society, Position Paper on Bukit Brown, January 2012.

${ }^{6}$ The last few years have seen some exceptions to this norm: Pulau Ubin, an island northeast of mainland Singapore known for its relatively unspoiled nature and wetlands, was spared reclamation, partly due to the campaigns from civil society groups. The dismantlement of the Keretapi Tanah Melayu, or Railway Corridor that linked Singapore's city centre (Tanjong Pagar Railway Station) with Malaysia, left $23 \mathrm{kms}$ of green space. Fears that the land would be released for development elicited actions from nature and heritage groups, chiefly SNS and SHS, which proposed to preserve the space as a "Green Corridor" that is still accessible.
} 
The sudden public outcry for BBMC's future was unexpected. According to the government it had been public knowledge that the long-term plan was to use the area to meet future housing needs (Singapore Government, 2011b). In fact, Bukit Brown has been zoned for residential use since the 1991 Concept Plan, and the 2001 Concept Plan even charted possible train routes running through it. Indeed until the 2011 announcement, Bukit Brown had not attracted much public attention, and many Singaporeans had never visited or heard of it (Ting, 2015, p. 13; Chong, 2015, p. 161). Until then, the main visitors paying their respects at the cemetery were gamblers, who brought food offerings and burned "hell money" (fake cash) in exchange for good luck with their bets (Tsang, 2007). Other visitors included families, who visited the cemetery during the annual tomb-sweeping Qing Ming Festival, naturalists who visited to examine its unique and relatively untouched flora and fauna, joggers, horseback riders, and members of some civil society groups such as the Singapore Heritage Society.

However, the government's announcement in 2011 unleashed a sort of 'heritage fever' in Singapore. Building up from previous cases where tangible heritage had been lost forever (e.g. Bidadari Cemetery, the National Library at Stanford Road, the National Theatre, the Van Kleef Aquarium), civil society groups in the country set out on a quest to save the tangibility of the cemetery, and if this was not possible, to preserve its intangibility. During the years that followed Bukit Brown Cemetery was in the popular discourse, and its slow-motion future disappearance triggered a reaction from ordinary citizens and the flourishing of grassroots initiatives rarely seen in Singapore (Chong, 2015, p. 161). Even some overseas Singaporean communities found a newly-discovered interest in tracing their ancestry back to Bukit Brown (Chong \& Chua, 2014, pp. 34-35).

The release of the government plans for the cemetery and the subsequent start of the construction of the highway activated this new heritage consciousness in Singapore's citizenry. Indeed the debate, which touched on national history and identity, went beyond BBMC itself, until then a stranger to many Singaporeans. Arguably, many of the preservation initiatives that followed would not have happened without this seminal incident. The outpouring on interest included: several books supported by Heritage boards and societies, Policy institutes and Memorial halls (Spaces of the Dead: A Case from the Living, War II @ Bukit Brown, Singapore Chronicles: Heritage, and 1911 Revolution: Singapore Pioneers in Bukit Brown); chapters in academic books ("The Multiple Spaces of Bukit Brown", in Public Space In Urban Asia, "Bukit Brown municipal cemetery: Contesting imaginations of the good life in Singapore", in Worlding Multiculturalisms: The Politics of Inter-Asian Dwelling); documentation projects (The Bukit Brown Cemetery Documentation Project) $;^{7}$ articles and reports in international media such as The Wall Street Journal, BBC, CNN, Voice of America News, The Economist, Xinhua News, CCTV, and The Guardian, among others; documentary films (Singapore cemetery - History from the hills, by OKTO, The Rites and Rituals of Bukit

\footnotetext{
7 The project was sponsored by the government's Land Transport Authority (LTA) and Urban Redevelopment Authority (URA), and led by Dr Hui Yew-Foong, a Senior Fellow at the Institute of Southeast Asian Studies. It documented the graves, but also the social history, memories and rituals associated with the cemetery, as well as the exhumation process.
} 
Brown Cemetery, by the National Heritage Board, Roots: a Documentary on Bukit Brown, by Singapore Polytechnic); exhibitions (The Bukit Brown Index); ${ }^{8}$ theatre plays and performances; ${ }^{9}$ and dedicated websites by heritage groups (All Things Bukit Brown (http://bukitbrown.com), and SOS Bukit Brown (https://sosbukitbrown.wordpress.com/). ${ }^{10}$

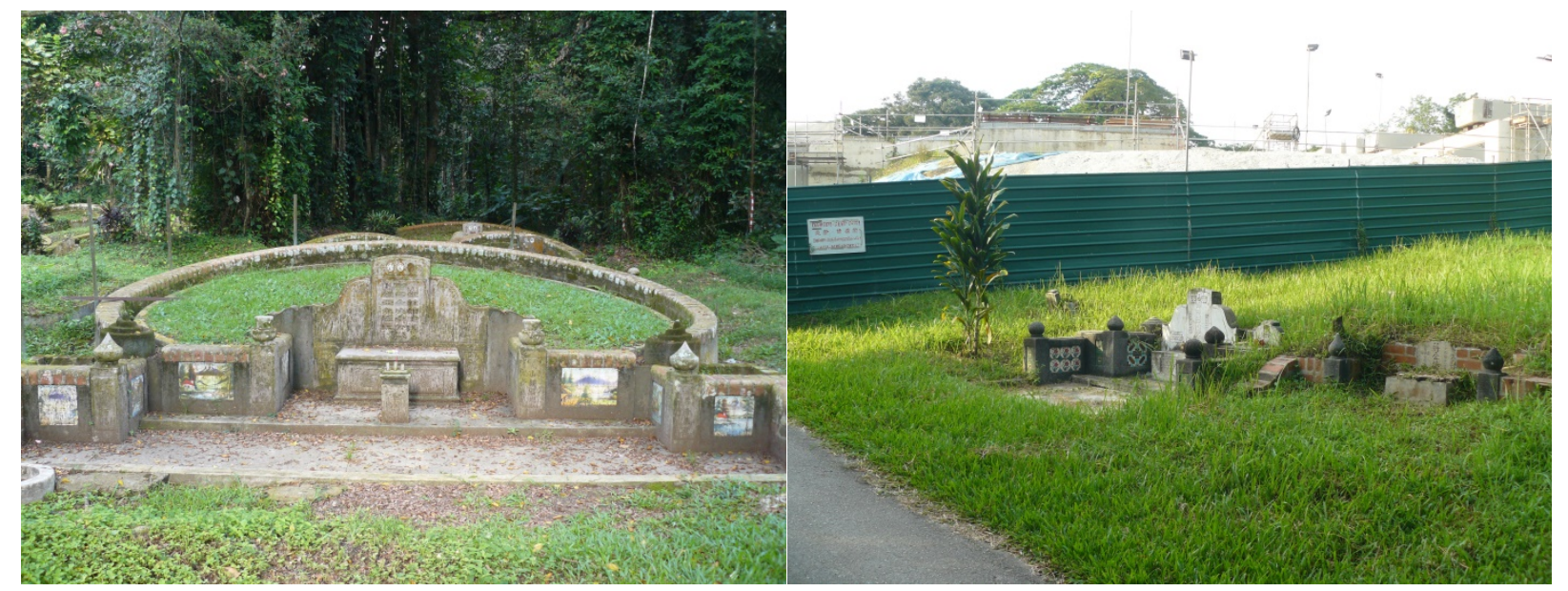

Figure 5. Shrine at Bukit Brown Cemetery (Author's photograph, 2017)
Figure 6. Construction of the eight-lane highway at Bukit Brown Cemetery (Author's photograph, 2017)

\section{Layers of meaning in the heritage riddle}

Donovan Rypkema affirms that in the twenty-first century "only the foolish city will make the choice between historic preservation and economic development. The wise city will utilize its historic built environment to meet the economic, social, and cultural needs of its citizens far into the future" (Rypkema, 2008). The re-discovery of Bukit Brown Cemetery by Singapore's civil society after the government's announcement to build the highway posed a fundamental and uncomfortable dichotomy of choice in the minds of many Singaporeans: what should come first, our heritage or development? It also unearthed many other layers of heritage meanings that branched into many other questions. In Singapore, where heritage issues had remained irrelevant to the majority of the population, Bukit Brown opened a 'heritage Pandora's box' containing many old and new questions:

\footnotetext{
${ }^{8}$ The Bukit Brown Index was part of Singapore Art Museum's Unearthed exhibition, and it included a mixed media installation with names on unclaimed graves from the cemetery written on a black wall.

${ }^{9}$ For instance, re-enactments of Jean Tay's Boom, a play about relocation of both dead and living and the inexorable march of progress, at DBS Arts Centre (Singapore, 2012), Warwick Arts Centre (UK, 2014), and NUS Centre for the Arts (Singapore, 2015); the tribute play It Won't Be Too Long: The Cemetery, directed by Kok Heng Leun, and performed at the School of the Arts (SOTA), and at Bukit Brown Cemetery, chosen as the closing act for Singapore International Festival of the Arts in 2015; and Trees, $A$ Crowd, a play by Irfan Kasban, that depicts a government decision about chopping down a tree to make way for a road, presented at the Twenty-Something Theatre Festival in 2016.

${ }^{10}$ It was as a result of a proposal by All Things Bukit Brown that in October 2013 Bukit Brown Cemetery was placed on the 2014 World Monuments Watch, which records global heritage sites which are at risk of being destroyed.
} 
- What is considered Singapore's most 'authentic heritage'? Organically multi-layered old cemeteries such as Bukit Brown, or more manicured yet outstanding spaces such as the Botanic Gardens? ${ }^{11}$

- Should ancestral rites such as the Qing Ming Festival and the Hungry Ghost Festivals, traditionally performed at cemeteries, be preserved? How can they be maintained when the tangibility of a cemetery is gone? Is documenting the graves enough for the descendants and the country's overall population?

- Can rapidly-growing and space-hungry Singapore afford green lungs like BBMC, often located in prime land ${ }^{12}$ Would that be sustainable? Does it contradict the government efforts to promote healthier lifestyles for its citizens? ${ }^{13}$

- Have Singapore's pioneers and those who died for the country during World War II not earned their right to rest in peace? Where does this right lie in a fast-moving global city?

- Does Singapore lose parts of its identity when it neglects the preservation of heritage landmarks like Bukit Brown? Can a mostly Chinese graveyard represent the identity of a multicultural and multiracial country like Singapore? If Bukit Brown were to be kept untouched, should other religion's burial grounds be also preserved?

\section{Development wins, but with concessions}

The construction of the highway crossing through Bukit Brown Cemetery is well underway and is scheduled to be completed by 2018. It is likely that in the decades to come the cemetery area will also see the construction of a residential estate, transportation infrastructure, and other facilities for future generations. As with previous cases, the Singapore government proceeded in spite of the heritage controversy, although this time with some notable nuances and concessions: in the final design of the highway, part of it was built as a bridge, hence diminishing impact on flora and fauna and helping to preserve natural drainage; as a result the number of graves affected also decreased from the estimated 5,000 to 3,746 (Singapore Government, 2012); exhumation of graves was also delayed by a few months to give family members more time to register the graves; the

\footnotetext{
${ }^{11}$ In 2013, the Singapore government decided not to nominate Bukit Brown Cemetery as a UNESCO Heritage Site, focusing on a bid, ultimately successful, for the Singapore Botanical Gardens. Mr Lawrence Wong, Acting Minister for Culture, Community and Youth, justified the decision in the following terms: "We recognize that there is heritage value in the Bukit Brown municipal cemetery. This is why government agencies, including the National Heritage Board (NHB), have been working with experts and stakeholders on various efforts to document and commemorate the memories of Bukit Brown for future generations.... Not all sites with local heritage value will qualify as a UNESCO World Heritage Site" (Response to NMP Ms Janice Koh by Mr Lawrence Wong, Acting Minister for Culture, Community and Youth, 9 July 2013, Parliamentary Question No. 40)

${ }^{12}$ The Nature Society of Singapore, praising the ecological value and biodiversity of the area, proposed that it be designated as a heritage park (Nature Society Singapore, 2011)

${ }^{13}$ See some of Singapore's Health Promotion Board campaigns at https://www.hpb.gov.sg/
} 
government commissioned and funded the documentation of the tombs to ensure detailed records of personal histories, heritage and rituals are kept (Singapore Government, 2011b).

As the Bukit Brown Cemetery conundrum shows, today Singaporeans are aware and knowledgeable of their own heritage, and are ready to disagree with government development plans where they see this heritage being violated. In a rapidly-changing country with a constantly-evolving society, heritage can be a delicate matter interweaving notions such as culture, history, identity, memory, and a sense of belonging. Dialogue is fundamental to ensure a balanced relationship between development and preservation, but also to maintain social harmony. For now, in land-scarce Singapore, where prisons share walls with hospitals, airports, villages and business parks, the space allocated for the dead is shortlived; the living get priority.

\section{Conclusion}

The aim of this study is to shed light on the complexity of heritage-making in major Asian cities. It also analyses how expansion and development can collide with the preservation of legacies, the past and memory. The three case studies outlined in this paper illustrate some of the main debates related to heritage preservation in today's major tropical Asian cities. In the case of Hong Kong's To Kwa Wan station, the heritage site was buried and unseen, and the dispute only emerged when the construction of the railway line unveiled the ancient historical relics from the Song and Yuan dynasties. In Manila's Rizal monument impasse, the heritage symbol was popular, visible and widely accessible to the public, and controversy sparked when a foreign element - a mega condominium - threatened its sightline. In Singapore's case of the century-old and previously largely unnoticed Bukit Brown Cemetery, the heritage clash arose when it was faced with the threat of damage or complete loss to development.

None of the three heritage preservation conundrums presented in this paper was resolved in a straightforward manner. In busy, land-scarce and rapidly-growing Asian cities, the management of heritage assets can easily turn into heritage dilemmas for policy-makers and governments. It is important then, that decision-makers realise that, as Hutter underlines, in heritage conservation the inevitable choices that must be made are rarely pure and simple (Hutter, 1997, p. 9). A few years ago, cases like the three investigated in this paper would have garnered little attention from the media and public. Today, however, government decisions about heritage are meticulously scrutinised by more heritage-conscious citizens and by better organised heritage groups. They are emboldened to speak up, are aware of their rights, and with access to powerful tools of social media, their voices count.

These three cases are just the underlying rhizomatic roots of a contemporary heritagemaking conundrum also present in other major tropical Asian cities such as Jakarta and Ho Chi Minh City, and in some large Indian and Chinese urban areas. Heritage preservation in this part of the world is a complex exercise, a dilemma that interacts today with what 
Rypkema describes as "a litany" of values: cultural, educational, aesthetic, environmental, social, historical, and economic (Rypkema, 2008). More research is necessary to unveil and analyse other cases, like those detailed in this paper, which can help facilitate a healthy and constructive heritage debate, where creative and imaginative views are presented and appropriate solutions are co-created.

\section{References}

\#DemolishTorreDeManila. (n.d.). Retrieved 09 March, 2018, from Change.org website: https://www.change.org

Aas, C., Fletcher, J. \& Ladkin, A. (2005). Stakeholder Collaboration and Heritage Management. Annals of Tourism Research, 32(1), 28-48. doi:10.1016/j.annals.2004.04.005

Alimario, A. \& Bacungan, V.J. (2017, April 05). Supreme Court defers ruling on Torre de Manila case. CNN Philippines. Retrieved from http://cnnphilippines.com

All Things Bukit Brown. (n.d). Retrieved July 18, 2017, from All Things Bukit Brown website: http://bukitbrown.com

Antiquities Advisory Board (2017). MTR Corporation, gov't propose redesigning To Kwa Wan station to preserve centuries-old relics. Retrieved from https://www.hongkongfp.com/2017/06/06/mtr-corporation-govt-propose-redesigningkwa-wan-station-preserve-centuries-old-relics/

Archaeology News Network. (2014, May 16). Discoveries At Hong Kong Rail Link Site Left In Limbo. [Web log message]. Retrieved from https://archaeologynewsnetwork.blogspot.sg

Aurelio, J.M. (2017, May 28). SC lifts Torre de Manila TRO. The Philippine Daily Inquirer. Retrieved from http://www.inquirer.com.ph

Au-Yong, R. (2017, July 18). Singapore's biggest and only active public cemetery will shrink by one-third to make way for Tengah Air Base. The Straits Times. Retrieved from www.straitstimes.com

Au-Yong, R. (2017, July 19). Size of Choa Chu Kang Cemetery to be cut by one-third to make way for Tengah expansion. The Straits Times. Retrieved from www.straitstimes.com

Banyan. (2013, April 01). Elegy for an urban graveyard. The Economist. Retrieved from https://www.economist.com/

Bendix, R. (2009). Heritage between economy and politics: An assessment from the perspective of cultural anthropology. In Smith, L. \& Akagawa, N. (Eds.), Intangible Heritage (pp. 253-269). Oxon: Routledge.

Calayag, K.A. (2017, April 05). Fate of Torre de Manila hangs as SC fails to deliberate anew. SunStar Philippines. Retrieved from http://www.sunstar.com.ph

Capels, V. \& Senville, W. (2006). Planning for Cemeteries. Planning Commissioners Journal, 64, 1-8. Retrieved from http://plannersweb.com/wp-content/uploads/2006/10/230.pdf

Chang, H.C. (2016, October 21). Bidadari - From graveyard to hot property. Property Guru. Retrieved from https://www.propertyguru.com.sg 
Chong, T. \& Chua, A.L. (2014). The Multiple Spaces of Bukit Brown. In Lim, W.S.W. (Ed.), Public Space in Urban Asia (pp. 26-55). Singapore: World Scientific Publishing Co. Pte. Ltd.

Chong, T. \& Yeo, K.S. (2013, April 18). Pulau Ubin and the unsettled S'pore psyche. Today. Retrieved from www.todayonline.com

Chong, T. (2015). Bukit Brown Municipal Cemetery: Contesting Imaginations of the Good Life in Singapore. In Goh, D.P.S (Ed.), Worlding Multiculturalism: The Politics of InterAsian Dwelling (pp.161-182). New York: Routledge.

Chun, H.W. (2011, November 09). Singapore Graveyard Stirs Lively Debate. The Wall Street Journal. Retrieved from https://blogs.wsj.com

Congress of the Philippines (2009). Republic Act No. 10066 - National Cultural Heritage Act of 2009, Article VII, Section 25, Power to Issue a Cease and Desist Order. Retrieved from http://www.lawphil.net/statutes/repacts/ra2010/ra_10066_2010.html

Dario, D. (2017, April 28). Timeline: Tracking the Torre De Manila case. The Philippine Star. Retrieved from http://www.philstar.com

Directo, J. (2015). Trees and reflective glass? Experts suggest ways to hide Torre de Manila. Retrieved from http://www.gmanetwork.com/news/lifestyle/content/508550/trees-andreflective-glass-experts-suggest-ways-to-hide-torre-de-manila/story/

DMCI Homes Says Tall Buildings Used to Surround Rizal Park (2015, October 09). Property Asia. Retrieved from https://www.propertyasia.ph

Felongoo, G. P. (2015, January 15). Philippines Heritage Watchdog Halts Construction of High-rise for Blocking the View of Rizal Shrine. Gulf News. Retrieved from www.gulfnews.com

Fung, F.W.Y. (2014a, May 03). Relics found at former Sacred Hill site before MTR's decision to build. South China Morning Post. Retrieved from wwww.scmp.com

Fung, F.W.Y. (2014b, May 23). Doubts cast over whether To Kwa Wan well is from Song or Yuan dynasty. South China Morning Post. Retrieved from wwww.scmp.com

Fung, F.W.Y. (2014c, June 14). Sai Kung rock may hold key to To Kwa Wan relics' history. South China Morning Post. Retrieved from wwww.scmp.com

Fung, F.W.Y. (2014d, July 06). Pottery found at To Kwa Wan shows city was trading hub back in Song dynasty. South China Morning Post. Retrieved from wwww.scmp.com

Fung, F.W.Y. (2014e, November 23). Medieval well may be moved from To Kwa Wan station construction site. South China Morning Post. Retrieved from wwww.scmp.com

Fung, F.W.Y. (2014f, December 09). Plans to preserve relics found at MTR building site go too far, cost too much, archaeologists say. South China Morning Post. Retrieved from wwww.scmp.com

Fung, F.W.Y. (2015, May 21). Systemic problems facing attempts to preserve Hong Kong's heritage. South China Morning Post. Retrieved from wwww.scmp.com

Galla, A. (Ed.) (2002). Protection of Cultural Heritage in Southeast Asia: Workshop Proceedings, Hanoi, Vietnam, 9-13 April 2001. Paris: International Council of Museums.

Goh, D.P.S. (2015). Introduction. In Goh, D.P.S. (Ed.), Worlding Multiculturalism: The Politics of Inter-Asian Dwelling. New York: Routledge. 
Gonzales, Y.V. (2017, April 25). DMCI welcomes 'fair, just' SC ruling on Torre de Manila. Inquirer.net. Retrieved from http://www.inquirer.net/

Government of Hong Kong, Legislative Council (2014). LCQ20: Archaeological excavation at To Kwa Wan Station of Shatin to Central Link [Press release]. Retrieved from http://www.info.gov.hk/gia/general/201412/17/P201412170465.htm

Han, K. (2015, August 7). Land-starved Singapore exhumes its cemeteries to build roads and malls. The Guardian. Retrieved from https://www.theguardian.com

Health Promotion Board. (n.d.). Retrieved November 21, 2017, from Health Promotion Board website: https://www.hpb.gov.sg/

Howard, P. (2003). Heritage: Management, Interpretation, Identity. London: Continuum

Hui, Yew-Foong (2012). Debating Bukit Brown: bringing a cemetery to life in Singapore. International Institute for Asian Studies: The Newsletter, 62

Hutter, M. (1997). Economic Perspectives on Cultural Heritage: An Introduction. In Hutter, M. \& Rizzo, I. (Eds.), Economic Perspectives on Cultural Heritage (pp. 3-10). London: Macmillan Press Ltd.

It Won't Be Too Long: The Cemetery. (n.d.). Retrieved June 17, 2017, from Singapore International Festival of Arts website: https://sifa.sg/2015/sifa/show/the-cemetery/

It Won't Be Too Long: The Cemetery. (n.d.). Retrieved June 19, 2017, from Intercultural Theatre Institute website: https://www.iti.edu.sg/events/it-wont-be-too-long-thecemetery/

Kao, E. (2014, June 02). Fears relics removed from To Kwa Wan MTR site. South China Morning Post. Retrieved from wwww.scmp.com

Kao, E. (2014, December 23). Hong Kong MTR gets legal reminder to protect relics at To Kwa Wan. South China Morning Post. Retrieved from wwww.scmp.com

Koboldt, C. (1997). Optimizing the Use of Cultural Heritage. In Hutter, M. \& Rizzo, I. (Eds.), Economic Perspectives on Cultural Heritage (pp. 50-73). London: Macmillan Press Ltd.

Knights of Rizal. Republic of the Philippines, Supreme Court, Manila: Petition for Injunction (2014, September 12). Retrieved from https://bangkanixiao.files.wordpress.com/2014/09/petition-final.pdf

Kong, L. (1993). Ideological hegemony and the political symbolism of religious buildings in Singapore. Environment and Planning D-Society \& Space, 11(1), 23-46. doi: $10.1068 / \mathrm{d} 110023$

Kong, L. (2002). In Search of Permanent Homes: Singapore's House Churches and the Politics of Space. Urban Studies, 30(9), 1573-1586. Retrieved from http://ink.library.smu.edu.sg/cgi/viewcontent.cgi?article=2987\&context=soss_researc $\mathrm{h}$

Kong, L. (2003). Value Conflicts, Identity Construction, and Urban Change. In Bridge, G. \& Watson, S. (Eds.), A Companion to the City (pp. 354-365). Oxford: Blackwell Publishers Ltd.

Kong, L. \& Yeoh, B.S.A (2003). The Politics of Landscapes in Singapore: Constructions of "Nation". New York: Syracuse University Press.

Lamb, K. (2013, January 25). Singapore Cemetery Demolition Angers Residents. Voice of America News. Retrieved from https://www.voanews.com 
Lee, A. (2014, May 02).Concern over future of MTR archaeological dig. South China Morning Post. Retrieved from wwww.scmp.com

Lee, A. (2014, May 18). Decision put off until September on relics at To Kwa Wan MTR station site. South China Morning Post. Retrieved from wwww.scmp.com

Leow, C. \& Lim, C. (Eds.) (2016). World War II @ Bukit Brown. Singapore: Ethos Books.

Lim, R. (2012, April 06). Singapore to drive road through historic cemetery. BBC News. Retrieved from www.bbc.com

Loi, R. (2014, February 15). Tomb sleuth. The Business Times. Retrieved from http://www.businesstimes.com.sg

Lui, J. (2016, August 29). Tomb hunting brothers do their bit to preserve Singapore heritage. The Straits Times. Retrieved from www.straitstimes.com

Macaraig, A. (2015, January 14). Heritage advocates hail Torre de Manila suspension order. Rappler. Retrieved from https://www.rappler.com

Marcelo, V. (2017, April 26). SC junks petition against project marring view of Rizal Monument. CNN Philippines. Retrieved from http://cnnphilippines.com

Martin, M. (2014, September 21). SIFA 2015: Drama Box's poignant tribute to Bukit Brown Cemetery. Today. Retrieved from www.todayonline.com

Martin, M. (2014, March 22). Unearthed: New territory for SAM? Today. Retrieved from www.todayonline.com

Nasser, N. (2003). Planning for Urban Heritage Places: Reconciling Conservation, Tourism, and Sustainable Development. Journal of Planning Literature, 17(4), 467-479. doi: $10.1177 / 0885412203251149$

National Heritage Board (Producer). (2015, September 27). The Rites and Rituals of Bukit Brown Cemetery [Video file]. Retrieved from https://www.youtube.com/watch?v=wjayXAmGyNs\&t=1s

Nature Society (Singapore) (2011). Nature Society (Singapore)'s Position on Bukit Brown. Retrieved from https://www.nss.org.sg/documents/Nature\%20Society\%27s\%20Position\%20on\%20B ukit\%20Brown.pdf

$\mathrm{Ng}$, E. (2017, June 06). MTR Corporation, gov't propose redesigning To Kwa Wan station to preserve centuries-old relics. Hong Kong Free Press. Retrieved from www.hongkongfp.com

$\mathrm{Ng}$, E. (2017, June 11). MTR criticised for 'lack of effort' in displaying centuries-old remains at To Kwa Wan station. Hong Kong Free Press. Retrieved from www.hongkongfp.com

Ng, K. (2017, July 19). 80,500 Choa Chu Kang graves to make way for Tengah Air Base expansion. Today. Retrieved from www.todayonline.com

No plans to nominate Bukit Brown for World Heritage site. (2013, July 09). Asia One. Retrieved from www.asiaone.com

Official Gazette of the Republic of the Philippines (1901). Act No. 243 (September 28, 1901). Retrieved from http://www.officialgazette.gov.ph/1901/09/28/act-no-243-s-1901/

Official Gazette of the Republic of the Philippines (2013). The Centenary of the Rizal Monument. Retrieved from http://www.officialgazette.gov.ph/rizal-monument/ 
OKTO (Producer). (2013, May 17). Singapore cemetery - History from the hills [Video file]. Retrieved from https://www.youtube.com/watch?v=wjayXAmGyNs

Ong, T.K. (2016, March 28). The rebirth of cemetery land in Singapore Jones Lang LaSalle. Retrieved from http://www.jllapsites.com

Porcalla, D. (2017, April 27). Fight vs Torre de Manila not over - Cayetano. The Philippine Star. Retrieved from http://www.philstar.com

Ramchandani, N. (2017, July 19). Farms, graves to make way for Tengah Air Base. The Business Times. Retrieved from http://www.businesstimes.com.sg

Ramchandani, N. (2017, July 18). Tengah Air Base undergoes expansion to free up land at Paya Lebar Air Base. The Business Times. Retrieved from http://www.businesstimes.com.sg

Ranada, P. (2013a, October 12). Manila councilor opposes 'Terror de Manila' condo.

Rappler. Retrieved from https://www.rappler.com

Ranada, P. (2013b, November 06). NHCP backs off from Torre de Manila issue. Rappler.

Retrieved from https://www.rappler.com

Ranada, P. (2013c, November 28). Manila city council suspends Torre de Manila construction. Rappler. Retrieved from https://www.rappler.com

Ranada, P. (2014a, January 30). Manila OKs Torre de Manila construction. Rappler.

Retrieved from https://www.rappler.com

Ranada, P. (2014b, August 04). Pia Cayetano to look into Torre de Manila violations.

Rappler. Retrieved from https://www.rappler.com

Ranada, P. (2014c, August 27). Pia Cayetano grills DMCI on 'good faith' in Torre de Manila Rappler. Retrieved from https://www.rappler.com

Ranada, P. (2014d, September 04). Pia Cayetano eyes charges vs DMCl over Torre de Manila. Rappler. Retrieved from https://www.rappler.com

Ranada, P. (2014e, September 12). SC asked to order Torre de Manila demolition. Rappler. Retrieved from https://www.rappler.com

Reformina, I. (2017, April 26). SC allows Torre de Manila construction ABS-CBN News. Retrieved from http://news.abs-cbn.com

Rojak Librarian (2013, April 02). Bukit Brown Cemetery: a UNESCO World Heritage Site.

[Web log message]. Retrieved from https://mymindisrojak.blogspot.sg/2013/04/bukitbrown-cemetery-unesco-world.html

Rojak Librarian (2013, July 09). Parliamentary Question by Ms. Janice Koh (Bukit Brown).

[Web log message]. Retrieved from https://mymindisrojak.blogspot.sg/2013/07/parliamentary-question-by-ms-janicekoh.html

Rypkema, D.D. (2008). Heritage Conservation and the Local Economy. Global Urban Development Magazine, 4(1). Rehoboth: Global Urban Development

Safford, L.B. (2013). Cultural Heritage Preservation in Modern China: Problems, Perspectives, and Potentials. ASIANetwork Exchange: A Journal for Asian Studies in the Liberal Arts, 21(1), 3-15. doi: http://doi.org/10.16995/ane.69

Samuel, R. (1994). Theatres of Memory. Vol. 1: Past and Present in Contemporary Culture. London: Verso, 1994. 
Saparudin, K. Bukit Brown Municipal Cemetery (2013). National Library Board. Retrieved from http://eresources.nlb.gov.sg/infopedia/articles/SIP_1358_2009-07-13.html

Sembrano, E.A.M. (2017, August 07). 'Rare' Art Deco wooden school in Binondo demolished. The Philippine Daily Inquirer. Retrieved from http://www.inquirer.com.ph

Senate of the Philippines. (2015). Statement of Sen. Pia S. Cayetano Chair, Senate Committee on Education, Arts and Culture [Press release]. Retrieved from http://www.senate.gov.ph/press_release/2015/0114_cayetano1.asp

Siau, M.E. (2013, August 07). Exhumation of Bukit Brown graves to start in Oct. Today. Retrieved from www.todayonline.com

Sin, Y. (2017, July 03). Oxley Road: Issues of national heritage need to be considered, say MPs. The Straits Times. Retrieved from www.straitstimes.com

Singapore Art Museum (2014). Unearthed [art catalogue]. Singapore: Singapore Art Museum Singapore Government, Singapore Statues Online (2009). Preservation of Monuments Act (Chapter 239): (Original Enactment: Act 16 of 2009) Revised Edition 2011. Retrieved from Singapore Statues Online website: http://statutes.agc.gov.sg

Singapore Government, Land Transport Authority. (2011a). Construction of New Dual FourLane Road to Relieve Congestion Along PIE \& Lornie Road and Serve Future Developments [Press release]. Retrieved from https://www.Ita.gov.sg/apps/news/page.aspx?c=2\&id=rj2i401u3d7018466v86y82epxjj 32mwbvnhu6rpwt8lplkgo6

Singapore Government, Land Transport Authority. (2011b). Partnering Stakeholders to Document Graves Affected by the New Road at Bukit Brown Cemetery [Press release]. Retrieved from https://www.Ita.gov.sg/apps/news/page.aspx?c=2\&id=xi3xxc1d3304j5hcino3vf422yv3 vhh8ofe5yhg02x9vi37by9

Singapore Government, Land Transport Authority. (2012). LTA Finalises alignment of New Road across Bukit Brown [Press release]. Retrieved from https://www.Ita.gov.sg/apps/news/page .aspx?c=2\&id=3409b41og5bkgr1vr0asqb8vm gzeso0ghnwn0212451i6dxwk8

Singapore Government, Land Transport Authority. (2013). Joint News Release by the Transport Authority \& URA - Tender to Construct New Road Across Bukit Brown Awarded [Press release]. Retrieved from https://www.Ita.gov.sg/apps/news/page.aspx?c=2\&id=a002bddb-761c-45e7-aa75b7747799739d

Singapore Government, National Environment Agency. (2017). Choa Chu Kang Exhumation Programme. Retrieved from National Environment Agency website: http://www.nea.gov.sg/public-health/care-for-the-dead/choa-chu-kang-exhumationprogramme

Singapore Government, Singapore Land Authority. (2017). Tengah Air Base to be expanded to free up Paya Lebar Air Base for future development [Press release].Retrieved from https://www.sla.gov.sg/News/articleid/648/parentld/97/year/2017?category=Press\%2 OReleases 
Singapore Heritage Society (2012). Position Paper on Bukit Brown. Retrieved from http://www.singaporeheritage.org/wpcontent/uploads/2011/11/SHS_BB_Position_Paper.pdf

Singapore Polytechnic's Diploma in Creative Writing for TV and New Media (Producer). (2016, February 27). Roots: a Documentary on Bukit Brown [Video file]. Retrieved from https://www.youtube.com/watch?v=f6Hw46Q9EtY

Sionil José, F. (2015, June 21). The Rizal Monument, the Supreme Court and patriotism The Philippine Star. Retrieved from http://www.philstar.com

SOS Bukit Brown. (n.d.). Retrieved July 18, 2017, from SOS Bukit Brown website: https://sosbukitbrown.wordpress.com/

South China Morning Post (2014). Excavation at MTR site could help prove Song dynasty's links to Hong Kong. Retrieved from http://www.scmp.com/news/hongkong/article/1523321/excavation-mtr-site-could-help-prove-song-dynastys-links-hongkong

Sun Yat Sen Nanyang Memorial Hall (2013). 1911 Revolution: Singapore Pioneers in Bukit Brown. Singapore: Sun Yat Sen Nanyang Memorial Hall

Supreme Court of the Philippines (2017). En Banc, G.R. No. 213948 (2017, April 18)

Tan, K.Y.L. (2011). Spaces for the Dead: A Case for the Living. Singapore: Ethos Books.

Tan, R. (2013, September 01). Singaporeans unfazed by Bidadari's cemetery past for panned HDB estate. The Straits Times. Retrieved from www.straitstimes.com

Teo, E. (2012, June 09). Cemeteries before, homes to die for now. Singapore Property News. Retrieved from http://www.stproperty.sg

The Bukit Brown Cemetery Documentation Project. (n.d.). Retrieved July 13, 2017, from The Bukit Brown Cemetery Documentation Project: http://www.bukitbrown.info/

The Civil Code of the Philipppines (1949). Republic Act No. 386, June 18, 1949: Book II, Art. 694 Tittle VIII.

Throsby, D. (1997). Seven Questions in the Economics of Cultural Heritage. In Hutter, M. \& Rizzo, I. (Eds.), Economic Perspectives on Cultural Heritage (pp.13-30). London: Macmillan Press Ltd.

Ting, K. (2015). Singapore Chronicles: Heritage. Singapore: Straits Times Press

To Kwa Wan station to display relics, says MTR. (2017, June 08). RTHK News. Retrieved from http://news.rthk.hk

Torre de Manila (n.d.). Retrieved September 15, 2017, from DMCI Homes website: https://www.dmcihomes.com/

Torres-Tupas, T. (2015, July 31). Torre de Manila developer: Photobombing not against the law. Inquirer.net. Retrieved from http://www.inquirer.net/

Tsang, S. (2007). Discover Singapore: the City's History \& Culture Redefined. Singapore: Marshall Cavendish Editions.

Tsui, E. \& Yau, E. (2016, May 31). More Hong Kong heritage being saved, but critics question uses it's being put to. South China Morning Post. Retrieved from wwww.scmp.com

Unearthing ties that bind us to Nature. (2014, March 21). The Business Times. Retrieved from http://www.businesstimes.com.sg 
UNESCO (1972). Recommendation concerning the Protection, at National Level, of the UNESCO Cultural and Natural Heritage. In Records of the General Conference, Seventeenth Session, Paris, 17 October to 21 November 1972, 146-154.

Urban Redevelopment Authority (1991). The Concept Plan 1991: Living the Next Lap. Singapore: Urban Redevelopment Authority.

Urban Redevelopment Authority (2001). The Concept Plan 2001. Singapore: Urban Redevelopment Authority.

Villanueva, M. A. (2015, July 06). National photo-bomber Torre de Manila. The Philippine Star. Retrieved from http://www.philstar.com

Weiss, L. (2007). Heritage-making and political identity. Journal of Social Archaeology, 7(3), 413-431. doi: $10.1177 / 1469605307081400$

Wong, O. \& Fung, F.W.Y. (2014, December 06). Preserved relics at future To Kwa Wan station 'should tell story'. South China Morning Post. Retrieved from wwww.scmp.com

Wong, O. (2014, November 20). Discovery of relics at Sha Tin-Central MTR site has cost HK\$3 billion. South China Morning Post. Retrieved from wwww.scmp.com

Yuen, B. (2005). Strengthening Urban Heritage in Singapore: Building Economic Competitiveness and Civic Identity, Global Urban Development Magazine, 1(1). Rehoboth: Global Urban Development

Yusof, H. (2015, December 25). A fine year for theatre. The Business Times. Retrieved from http://www.businesstimes.com.sg

Yusof, H. (2016, June 03). Voices from the millennial generation. The Business Times. Retrieved from http://www.businesstimes.com.sg

Zaccheus, M. (2015, September 30). Bukit Brown's iconic gates to be refurbished, relocated. The Straits Times. Retrieved from www.straitstimes.com 